\title{
APONTAMENTOS SOBRE DIREITO E ESTADO EM TEORIA GERAL DO DIREITO E MARXISMO
}

\author{
Vinícius \\ Casalino $^{1}$
}

Gomes

\section{Resumo}

O artigo tem como objeto a obra de Evgeny Pachukanis, Teoria geral do direito e marxismo, publicada em 1924, na União Soviética. Parte-se da concepção original do autor, que aproxima a forma mercantil da forma jurídica, para identificar o caráter específico da relação entre direito e Estado em sua análise. Delimitada a questão, procura-se ressaltar os limites teóricos de sua teoria, sobretudo a permanência em categorias que expressam a circulação simples de mercadorias, o que relega a segundo plano a circulação complexa e a compra e venda da força de trabalho. Como consequência, a luta de classes acaba ocupando um plano analítico inferior, o que compromete, em parte, sua concepção sobre Estado. Conclui-se apontando caminhos interpretativos que deem conta de suprir a ausência de importantes conexões categoriais, sempre à luz da dialética marxiana.

Palavras-chave: Marxismo e direito; forma mercantil e forma jurídica; direito e Estado; Evgeny Pachukanis; Crítica marxista do direito e do Estado.

\section{INTRODUÇÃO}

Desde a sua publicação, em 1924, Teoria geral do direito e marxismo, de Evgeny Pachukanis, alcançou lugar privilegiado e também muito peculiar na tradição de estudos marxistas sobre direito e Estado ${ }^{2}$. O ponto mais evidente, sem dúvida, é a original aproximação entre direito e mercadoria, isto é, entre forma jurídica e forma mercantil ${ }^{3}$, que marca não apenas uma crítica fundamental ao positivismo jurídico - o que era de se esperar -, como também um

\footnotetext{
${ }^{1}$ Pós-doutorado em andamento pelo Departamento de Economia da Faculdade de Economia, Administração e Contabilidade da Universidade de São Paulo (FEA-USP). Doutor e Mestre pelo Depertamento de Filosofia e Teoria Geral do Direito da Faculdade de Direito da Universidade de São Paulo (Largo São Francisco-USP). Professor da Faculdade de Direito da Pontifícia Universidade Católica de Campinas (PUCCAMP). E-mail: viniciuscasalino@gmail.com

${ }^{2}$ Sobre a vida e obra de Pachukanis, confira-se: (ALVES, 1988, pp. 5/6) e (NAVES, 2009, pp.11/19).

${ }^{3}$ Pachukanis observa no prefácio à $2^{\mathrm{a}}$ edição (1926): “O companheiro P. I. Stucka definiu, muito corretamente, a minha posição com relação à teoria geral do direito, como uma 'tentativa de aproximar a forma do direito da forma da mercadoria'. Na medida em que o balanço final permite julgar, essa ideia foi reconhecida em geral, e salvo algumas reservas, como feliz e frutuosa". (PACHUKANIS, 1988, p.08; 2003, p.36).
} vol.09, n. 03, Rio de Janeiro, 2016. pp. 
afastamento decisivo com relação a determinadas perspectivas marxistas relativas ao direito, centradas no paradigma estatal ${ }^{4}$.

Em que pese a importância da aproximação, que constitui evidentemente o eixo central de sua teoria e figura como objeto de inúmeras análises ${ }^{5}$, há outro aspecto de seu pensamento, igualmente relevante, e que também tem despertado a atenção de teóricos e pesquisadores. Trata-se da relação entre direito e Estado, sobretudo das consequências que a aproximação entre direito e mercadoria provoca na pesquisa da forma estatal e, subsequentemente, na formulação de uma teoria do Estado.

No início da década de 1920, as análises marxistas ancoravam-se em textos clássicos de Marx e Engels, cujo aspecto acentuadamente político punha em evidência a centralidade da luta de classes para a configuração da forma estatal ${ }^{6}$. Pachukanis introduz, no entanto, um elemento "complicador": sem menosprezar o papel que a luta de classes desempenha nesse contexto, assinala que é preciso considerar, de modo especial, a posição do direito como elemento central da sociabilidade capitalista, o que conduz, por sua vez, à relevância da mercadoria e da circulação mercantil na configuração da forma estatal. Se, como diz Marx, a mercadoria é a forma elementar de riqueza nas sociedades onde reina o modo de produção capitalista ${ }^{7}$, não há como pretender uma teoria do Estado sem colocar como eixo fundamental de análise a forma mercantil e a forma jurídica.

Assim, Pachukanis pôs em dúvida certo aspecto do pensamento de Engels, justamente no ponto em que o alemão assinala a gênese da forma estatal no conflito entre classes sociais ${ }^{8}$. O

\footnotetext{
${ }^{4}$ A propósito, Stutchka: "Na realidade, não identificamos o direito com a lei, tal como veremos a seguir, porém reconhecemos plenamente o Estado como poder que mantém determinado direito e, em grande parte, o forma". (STUTCHKA, 2001, p.85).

${ }^{5}$ Em âmbito internacional, verifique-se, entre outros: (CERRONI, 1976) e (EDELMAN, 1976). No Brasil, especialmente: (NAVES, 2000) e (MASCARO, 2007). Para uma análise da concepção de Pachukanis sobre direito penal, veja-se: (MASTRODI; FURQUIM; 2014).

${ }^{6}$ Do Manifesto comunista vem, por exemplo, a tão famosa quanto mal compreendida assertiva: "O executivo no Estado moderno não é senão um comitê para gerir os negócios comuns de toda a classe burguesa". (MARX; ENGELS, 1998, p.42; 2009, p.14). Em 1917, Lenin leva esta concepção às últimas consequências: "O Estado é a organização especial de uma força, da força destinada a subjugar determinada classe". (LENIN, 1986, p.31). Não se olvide, contudo, a existência de obras que buscaram uma análise mais aprofundada da questão, pondo em evidência outros aspectos do pensamento marxianos, tais como a relação entre reificação e consciência de classe. Nesse sentido, confira-se: (LUCKÁCS, 2003, pp.193-411).

${ }^{7}$ (MARX, 2013, p. 113; 1962, p. 49).

${ }^{8}$ São as seguintes passagens de $A$ origem da família, da propriedade privada e do Estado, contestadas por Pachukanis: "Mas para que esses antagonismos, essas classes com interesses econômicos colidentes não se devorem e não consumam a sociedade numa luta estéril, faz-se necessário um poder colocado aparentemente por cima da sociedade, chamado a amortecer o choque e a mantê-lo dentro dos limites da 'ordem'. Este poder, nascido da sociedade, mas posto acima dela se distanciando cada vez mais, é o Estado" (...) "Como o Estado nasceu da necessidade de conter o antagonismo das classes, e como, ao mesmo tempo, nasceu em meio ao conflito delas, é, por regra geral, o Estado da classe mais poderosa, da classe economicamente dominante, classe que, por intermédio dele, se converte também em classe politicamente dominante e adquire novos meios para a repressão e exploração da classe oprimida". (ENGELS, 2002, pp. 191/193, passim).
} 
autor russo chama a atenção para alguns paradoxos, tais como a noção de que o Estado estaria "acima" das classes sociais ou de que seria o resultado da "vitória" de uma sobre outra. Ressaltando as insuficiências destes pontos de vista, Pachukanis formula a indagação que se tornaria clássica:

Por detrás de todas essas controvérsias encontra-se camuflada uma mesma e única questão fundamental: por que é que o domínio da classe não se mantém naquilo que é, a saber, a subordinação de uma parte da população a outra? Por que é que ele reveste a forma de um domínio estatal oficial ou, o que significa o mesmo, por que é que o aparelho de coação estatal não se impõe como aparelho privado da classe dominante, por que é que ele se separa desta última e reveste a forma de um aparelho de poder público e impessoal, deslocado da sociedade? (PACHUKANIS, 1988, p.95; 2003, p.139).

O que está em jogo, no fundo, é a compreensão da forma de dominação política específica do capitalismo, o que remete necessariamente ao caráter histórico do Estado moderno $^{10}$. Se, como afirma Engels, a gênese da forma estatal encontra-se no antagonismo entre classes sociais - o que Pachukanis não nega -, o que se deve explicar é por que razão, no modo de produção capitalista, esse antagonismo não aparece como submissão explícita de uma classe social a outra, como ocorria no escravismo ou feudalismo, mas, pelo contrário, constitui-se como "domínio estatal oficial", como "aparelho de poder público impessoal, deslocado da sociedade”. Em outras palavras, por que o domínio do capital sobre o trabalho não se dá diretamente, mas é mediado por uma forma política que se separa da classe dominante e mantém-se autonomamente como "Estado"?

Eis a clivagem essencial que marcará todo o debate sobre Estado no marxismo ao longo do século XX, ao menos sob a perspectiva daqueles que buscam uma análise mais rigorosa ${ }^{11}$.

\footnotetext{
${ }^{9}$ E arremata: "Não podemos nos contentar com a explicação segundo a qual é vantajoso para a classe dominante erigir um cenário ideológico e camuflar o seu domínio de classe por trás do para-vento do Estado. Por que, embora tal explicação seja, sem dúvida alguma, correta, ela não determina a razão para que tal ideologia possa nascer também, por conseguinte, por que razão a classe dominante possa servir-se dela". (PACHUKANIS, 1988, p.95; 2003, p.139/140).

${ }^{10}$ Nesse sentido, depreende-se que "Estado moderno" é um pleonasmo, pois só há Estado na modernidade, isto é, com o advento do capitalismo. Joachim Hirsch explica: "O Estado é a expressão de uma forma social determinada que assumem as relações de domínio, de poder e de exploração nas condições capitalistas (...) A forma política, ou o Estado, é ela mesma parte integrante das relações de produção capitalistas. A particularidade do modo de socialização capitalista reside na separação e na simultânea ligação entre 'Estado' e 'sociedade', 'política' e 'economia'”. (HIRSCH, 2010, p.24/31, passim). Também é o ponto de vista de Alaôr Caffé Alves: "O Estado, portanto, tem características peculiares que só cabem ser consideradas no âmbito de um modo específico de realização material da vida social, ou seja, do modo capitalista de produção". (ALVES, 1987, p.212). Finalmente, Mascaro: "O Estado, tal qual se apresenta na atualidade, não foi uma forma de organização política vista em sociedades anteriores da história. Sua manifestação é especificamente moderna, capitalista". (MASCARO, 2013, p.17).

${ }^{11}$ Em 1979, Ruy Fausto notava: "No que dissemos, já há um resultado. Com efeito, as tentativas de elaborar uma teoria marxista do Estado fracassaram em geral até aqui, por não terem definido as exigências e condições dessa teoria (...) Com uma exceção, só recentemente a situação se modificou. Sobretudo na Alemanha, se assistiu a uma retomada da problemática do Estado em bases lógicas mais sólidas, na base de uma compreensão mais profunda da apresentação de $O$ capital (...) A exceção é o livro de Pasukanis (...) Estamos vol.09, nº 03, Rio de Janeiro, 2016. pp. 
Desse modo, parte dos autores inclinou-se pela abordagem proposta por Pachukanis, pondo em relevo a centralidade de categorias da crítica marxiana da economia política, tais como mercadoria, dinheiro, valor, e correspondentes formas jurídicas, tais como sujeito de direito, direito subjetivo, ideologia jurídica, como elementos centrais à identificação e compreensão da forma estatal ${ }^{12}$. Por outro lado, segmento importante de autores houve por bem retonar ao pensamento clássico, ressaltando as insuficiências daquela perspectiva e colocando em evidência a importância da luta de classes como momento fundamental à configuração do Estado ${ }^{13}$.

Pois bem, este artigo sustenta a hipótese de que a teoria de Pachukanis está marcada por um vácuo de significação, uma vez que a análise da relação entre direito e Estado funda-se imediatamente em categorias que expressam a circulação simples de mercadorias e deixa de lado elementos relacionados à circulação complexa, compra e venda da força de trabalho etc., de modo que a luta de classes acaba relegada a segundo plano, o que compromete, em parte, sua concepção sobre a forma estatal. No entanto, ao contrário da crítica tradicional, que vê a preeminência do conflito de classes como chave para a explicação da gênese do Estado, sustenta-se que a solução adequada consiste em posicionar adequadamente todos esses elementos no contexto da totalidade social à luz da dialética marxiana exposta em $\mathrm{O}$ capital. Desse modo, os polos da antinomia, as categorias mercantis e a luta de classes, dissolvem-se em oposição e revelam-se como momentos que constituem reciprocamente seus significados.

A adequada compreensão da gênese e natureza do Estado sob a óptica marxista está longe de ser uma questão de interesse meramente filosófico ou acadêmico. A queda do muro de Berlim, o esfacelamento da URSS, a crise "financeira" de 2008, o lento e contínuo desmonte do Estado de bem-estar social na Europa, e, sobretudo, o que parece ser a reversão de importantes conquistas sociais na América Latina põem a análise da forma estatal na ordem do dia. Afinal, mais do que mero "comitê gestor dos interesses da burguesia", a história recente mostra que o

convencidos que fora o livro de Pachukanis, A Teoria Geral do Direito e o Marxismo, os únicos textos que poderiam ter interesse para uma teoria do Estado desenvolvida a partir de $O$ capital são alguns textos alemães recentes". (FAUSTO, 1987b, p.288, corpo do texto e nota de rodapé no 04 e p.289, passim).

${ }^{12}$ Sob esta perspectiva, Gert Schäfer é contundente ao comentar certas passagens de A origem da família, da propriedade privada e do Estado: "Entretanto, não foi possível demonstrar que a 'condensação da sociedade civil na forma do Estado' (...) e o processo de constituição da 'vontade geral' dos proprietários de mercadorias (...) são uma consequência das formas contraditórias e das condições da produção de mercadorias. Ao invés disso, passou-se a supor, agora como depois, que existem, do ponto de vista da construção metódica e do processo de argumentação interno, relações diretas de dominação, formas imediatas de dominação de classes mesmo que estas, se excetuarmos os processos de crise e de revolução, não sejam realmente constitutivas para a formação capitalista da sociedade. Noutras palavras: a ideia de que o Estado é o 'produto e a manifestação da irreconciliabilidade das oposições de classe', não foi extraída da crítica da economia política e sim, desenvolvida através de uma 'sociologia da dominação' que de marxista só traz a aparência". (SCHÄFER, 1990, p.101).

${ }^{13}$ Uma das críticas mais incisivas encontra-se em: (POULANTZAS, 2000, pp.48/49) vol.09, nº. 03, Rio de Janeiro, 2016. pp. 
Estado é um importante locus de disputa pela redistribuição do mais-valor extraído à classe trabalhadora e destinado, cada vez mais e em maiores proporções, exclusivamente ao capital.

\section{SUJEITO DE DIREITO E FORMA DO ESTADO}

O eixo central da teoria de Pachukanis, aquilo que torna sua obra seminal, é a aproximação entre forma mercantil e forma jurídica ${ }^{14}$. O que marca a genialidade desta perspectiva, contudo, não é tanto seu ineditismo, mas o fato de representar uma leitura muito refinada e cuidadosa da obra magna de Karl Marx. Em outras palavras, Pachukanis não descobriu nada de absolutamente novo, mas teve o admirável mérito de perceber o óbvio, aquilo que nenhum marxista havia notado: as trocas de mercadorias engendram relações jurídicas, algo que Marx já havia assinalado. De fato, o capítulo 02 do Livro I de O capital é aberto da seguinte maneira:

As mercadorias não podem ir por si mesmas ao mercado e trocar-se umas pelas outras. Temos, portanto, de nos voltar para seus guardiões, os possuidores de mercadorias. Elas são coisas e, por isso, não podem impor resistência ao homem. Se não se mostram solícitas, ele pode recorrer à violência; em outras palavras, pode tomá-las à força. Para relacionar essas coisas umas com as outras como mercadorias, seus guardiões têm que estabelecer relações uns com os outros como pessoas cuja vontade reside nessas coisas e agir de modo tal que um só pode se apropriar da mercadoria alheia e alienar a sua própria mercadoria em concordância com a vontade do outro, portanto, por meio de um ato de vontade comum a ambos. Eles têm, portanto, de se reconhecer mutuamente como proprietários privados. Essa relação jurídica, cuja forma é o contrato, seja ela legalmente desenvolvida ou não, é uma relação volitiva, na qual se reflete a relação econômica. O conteúdo dessa relação jurídica ou volitiva é dado pela própria relação econômica. Aqui, as pessoas existem umas para outras apenas como representantes da mercadoria e, por conseguinte, como possuidoras de mercadorias (MARX, 2013, pp. 159-160; 1962, pp. 99-100, grifo meu).

Perceba-se que toda uma série de indagações sobre a origem ou natureza do direito é como que "resolvida" num único parágrafo. O direito não é o sentido normativo de um ato de vontade, como sustentavam os positivistas, notadamente Kelsen ${ }^{15}$, e tampouco se qualifica como forma de dominação que provém da classe que está no poder, como supunham alguns marxistas, sobretudo Stutchka ${ }^{16}$. Pelo contrário, a especificidade da forma jurídica reside na troca mercantil, de modo que o enlace de vontades iguais e autônomas, quer dizer, o contrato pactuado entre os possuidores de mercadorias, reconhecido legalmente ou não, é a nota própria da relação

\footnotetext{
14 Uma análise descritiva da teoria de Pachukanis encontra-se, entre outros, em: (NAVES, 2000) e (KASHIURA, 2009). Para uma abordagem crítica, veja-se: (CASALINO, 2011) e (SARTORI, 2014).

15 "Neste ponto importa salientar que a norma, como o sentido específico de um ato intencional dirigido à conduta de outrem, é qualquer coisa de diferente do ato de vontade cujo sentido ela constitui. Na verdade, a norma é um dever-ser e o ato de vontade de que ela constitui o sentido é um ser". (KELSEN, 1995, p.6).
} vol.09, $\mathrm{n}^{\mathrm{o}}$. 03, Rio de Janeiro, 2016. pp. 
de direito. Como afirma Marx, "o conteúdo da relação jurídica ou volitiva é dado pela própria relação econômica". O direito é, portanto, uma relação social; a forma específica da relação de troca.

Não bastasse o pioneirismo desta leitura, que identifica os traços essenciais da concepção marxiana sobre o direito, Pachukanis ainda coloca em relevo algo que até então passava despercebido mesmo pelas análises marxistas mais cuidadosas: o possuidor da mercadoria, aquele que a leva ao mercado com o intuito da troca é, do ponto de vista jurídico, a conhecidíssima figura da pessoa ou sujeito de direito. Como explica Marx, "para relacionar essas coisas umas com as outras como mercadorias, seus guardiões têm que estabelecer relações uns com os outros como pessoas cuja vontade reside nessas coisas". À forma mercantil do produto do trabalho corresponde a forma de pessoa do guardião do produto. O sujeito de direito não é, pois, um ente abstrato da razão ou uma figura criada pela norma jurídica. Sua origem concreta é a troca de mercadorias que ocorre no momento econômico ${ }^{17}$. Por fim, Pachukanis percebe que esta categoria é o núcleo essencial e indecomponível da teoria do direito, portanto, o ponto de partida da análise científica. $\mathrm{O}$ autor observa:

Toda relação jurídica é uma relação entre sujeitos. O sujeito é o átomo da teoria jurídica, o seu elemento mais simples, que não se pode decompor. É por essa razão que começaremos nossa análise pelo sujeito (PACHUKANIS, 1988, p.68; 2003, p.109).

Ora, se a riqueza da sociedade capitalista aparece como uma imensa coleção de mercadorias, e a forma mercantil é a gênese concreta da forma jurídica, então se pode afirmar que essa sociedade aparece também como o "reverso da moeda", ou seja, uma gigantesca cadeia de relações jurídicas ${ }^{18}$. Assim, a forma do sujeito de direito remete a certos signos de sociabilidade que são peculiares à sociedade mercantil, quais sejam: igualdade fundada na equivalência, liberdade como autonomia da vontade e propriedade privada. Desse modo, com a generalização do circuito de trocas, que se torna algo absolutamente trivial no capitalismo,

16 "O direito, tal como o Estado, são, nada mais nada menos, do que atributos ou formas de dominação de classe". (STUTCHKA, 2001, p.86).

${ }^{17}$ No prefácio à $2^{\mathrm{a}}$ edição, Pachukanis observa: "Depois de Marx, a tese fundamental, a saber, de que o sujeito jurídico das teorias do direito se encontra numa relação muito íntima com o proprietário das mercadorias, não precisava mais uma vez ser demonstrada". (PACHUKANIS, 1988, p. 08; 2003, p. 36). Por outro lado, não parece exagero afirmar que Marx chega a essa tese fundamental após a leitura atenta e rigorosa de Princípios da filosofia do direito, de Hegel. Note-se que, de acordo com o item 36 da obra hegeliana, a pessoa é o fundamento do direito abstrato: "É a personalidade que principalmente contém a capacidade do direito e constitui o fundamento (ele mesmo abstrato) do direito abstrato. O imperativo do direito é, portanto: sê uma pessoa e respeita os outros como pessoa". (HEGEL, 1997, p. 40).

${ }^{18}$ Pachukanis anota: "Do mesmo modo que a riqueza da sociedade capitalista reveste a forma de uma enorme acumulação de mercadorias, também a sociedade, em seu conjunto, apresenta-se como uma cadeia ininterrupta de relações jurídicas. A troca de mercadorias pressupõe uma sociedade atomizada. O vínculo entre as diferentes unidades econômicas privadas e isoladas é mantido a todo momento graças aos contratos que 
surgem como um dado da realidade os signos pelos quais a pessoa ou o sujeito de direito é considerado, por presunção social, um proprietário privado, livre, igual e autônomo em sua vontade. A compra e venda de bens, dentre os quais a própria força de trabalho, apenas tem lugar quando os proprietários ajustam suas vontades, repeitando mutuamente sua liberdade contratual. Como nenhum deles abre mão de sua mercadoria por um valor inferior àquele fixado objetivamente pelo mercado, a relação é caracterizada pela equivalência. Ao fetiche da mercadoria corresponde o fetiche do sujeito de direito, de modo que não apenas indivíduos são considerados pessoas, como também a reunião de suas vontades ou de seu patrimônio, vale dizer, a chamada "pessoa jurídica".

A centralidade desta categoria acarreta certas consequências na análise da relação entre direito e Estado. A primeira delas situa-se justamente no interior do debate marxista: trata-se de reconhecer a precedência da forma jurídica no que concerne à forma estatal, ou, em outras palavras, a proeminência da superestrutura jurídica com relação à superestrutura política. Se, como afirma a tradicional lição marxiana, a infraestrutura econômica é a base sobre a qual se elevam as formas jurídicas e de Estado ${ }^{19}$ e, no capitalismo, a primeira é conformada por relações de troca mercantil que projetam, como o outro lado da moeda, relações entre sujeitos de direito, então se conclui que a forma estatal é um momento logicamente posterior, isto é, cuja compreensão depende do desvendamento precedente da forma do direito. Pachukanis observa:

Marx mesmo salienta, contudo, que as relações de propriedade, que constituem a camada fundamental e mais profunda da superestrutura jurídica, se encontram em contato tão estreito com a base, que surgem como sendo as 'próprias relações de produção' das quais são a 'expressão jurídica'. O Estado, ou seja, a organização do domínio político de classe, nasce no terreno de dadas relações de produção e de propriedade. As relações de produção e a sua expressão jurídica formam aquilo que Marx chamava de, na sequência de Hegel, a sociedade civil. A superestrutura política e, notadamente, a vida política estadual oficial constituem um momento secundário e derivado (PACHUKANIS, 1988, p.52; 2003, p.90).

Fixada esta primeira premissa, de que a superestrutura jurídica precede a política, não há como deixar de concluir que a forma do Estado depende da forma do direito, ou, em outras palavras, que a natureza específica da organização estatal é conformada pela maneira particular como são engendradas as relações jurídicas na infraestrutura econômica da sociedade. Considerando que o sujeito de direito é o átomo do tecido jurídico, isto é, o elemento que não

celebram. A relação jurídica entre os sujeitos não é mais que o reverso da relação entre os produtos do trabalho tornados mercadorias". (PACHUKANIS, 1988, p. 47; 2003, p. 84).

${ }^{19}$ Trata-se da famosa passagem do Prefácio de Contribuição à crítica da economia política: "Nas minhas pesquisas cheguei à conclusão de que as relações jurídicas - assim como as formas de Estado - não podem ser compreendidas por si mesmas, nem pela dita evolução geral do espírito humano, inserindo-se, pelo contrário, nas condições materiais de existência de que Hegel, à semelhança dos ingleses e franceses do século XVIII, vol.09, n'. 03, Rio de Janeiro, 2016. pp. 1244 
pode ser descomposto, conclui-se que a forma do Estado emana da forma do sujeito, quer dizer, sua estrutura interna é determinada pelas características essenciais daquela figura: igualdade, liberdade, autonomia da vontade e propriedade privada.

Nesse sentido, é impossível que a vontade de uma das partes da relação contratual seja simplesmente imposta à outra nas situações em que o circuito econômico, por qualquer razão, não se complete. Se os termos do contrato não forem cumpridos - o que se dá com certa frequência no quotidiano da economia capitalista -, uma das partes não pode impor por conta própria o cumprimento daquilo que foi pactuado. Se isto ocorrer, surge o risco de restarem eliminados os pressupostos mais essenciais da economia mercantil, vale dizer, os signos que emergem como presunção social e que atribuem à forma do sujeito os caracteres de igualdade, liberdade, autonomia da vontade e propriedade privada como dados naturais inerentes à condição de pessoa.

Desse modo, a forma mercantil e, por consequência, a forma jurídica, exigem um terceiro elemento, aparentemente acima das partes, supostamente imparcial, capaz de fazer valer os termos do contrato que não foi cumprido. Esta é precisamente a gênese da forma do Estado, isto é, os elementos infraestruturais que determinam seu modo de ser, sua estrutura interna. Pachukanis observa:

Na medida em que a sociedade representa um mercado, a máquina do Estado estabelece-se, com efeito, como uma vontade geral, impessoal, como autoridade do direito etc. No mercado, como já foi visto, cada consumidor e cada vendedor é um sujeito jurídico por excelência. Nesse momento, quando entram em cena as categorias do valor, e do valor de troca, a vontade autônoma dos que trocam impõe-se como condição indispensável. O valor de troca deixa de ser valor de troca, a mercadoria deixa de ser mercadoria quando as proporções da troca são determinadas por uma autoridade situada fora das leis inerentes ao mercado. A coação, enquanto imposição fundamentada na violência colocando um indivíduo contra o outro, contradiz as premissas fundamentais das relações entre proprietários de mercadorias. É por isso que numa sociedade de proprietários de mercadorias e dentro dos limites do ato de troca, a função de coação não pode aparecer como uma função social, visto que ela não é abstrata e impessoal. A subordinação a um homem como tal, enquanto indivíduo concreto, significa na sociedade de produção mercantil a subordinação a um arbítrio, uma vez que isso equivale à subordinação de um proprietário de mercadorias a outro. Eis a razão por que também aqui a coação não pode surgir sob a forma não camuflada, como um simples ato de oportunidade. Ela deve aparecer antes como uma coação proveniente de uma pessoa coletiva abstrata e que é exercida não no interesse do indivíduo donde provém, pois numa sociedade de produção mercantil cada homem é um homem egoísta, porém, no interesse de todos os membros que participam das relações jurídicas. $\mathrm{O}$ poder de um homem sobre o outro expressa-se na realidade como poder do direito, isto é, como poder na norma objetiva imparcial (PACHUKANIS, 1988, pp. 97/98; 2003, pp.142/143).

compreende o conjunto pela designação de 'sociedade civil'; por seu lado, a anatomia da sociedade civil deve ser procurada na economia política”. (MARX, 2003, p.04/05).

vol.09, nº. 03, Rio de Janeiro, 2016. pp. 
A interpretação tradicional do pensamento de Pachukanis, que adota uma linha eminentemente descritiva, aponta na relação entre a forma do sujeito de direito e a forma estatal o essencial de sua concepção sobre o $E \operatorname{stado}^{20}$. Por outro lado, as críticas mais contundentes à perspectiva do autor russo colocam em evidência justamente os limites desta relação, uma vez que despreza o importante papel desempenhado pela luta de classes ${ }^{21}$. Do que se trata, portanto, é de verificar o rigor de ambas as leituras, quer dizer, de indagar até que ponto Teoria geral do direito e marxismo admite a extração da forma do Estado da esfera da circulação e até que ponto a luta de classes é alheia à sua análise.

\section{A LUTA DE CLASSES}

No prefácio à segunda edição de sua obra, Pachukanis refuta uma série de críticas dirigidas à sua concepção. Dentre elas, o argumento segundo o qual seu ponto de vista seria adequado à análise do direito comercial da sociedade burguesa, mas pouco teria a dizer sobre "as particularidades fundamentais e primárias da superestrutura jurídica enquanto fenômeno objetivo" (PACHUKANIS, 1988, pp. 09/10; 2003, p.38). Segundo o autor, a crítica teria negligenciado dois pontos: primeiro, que o princípio da subjetividade jurídica "não é somente um meio dissimulatório e um produto da hipocrisia burguesa", mas é um "princípio realmente atuante, que se acha incorporado na sociedade burguesa desde que nasceu da sociedade feudal e patriarcal e a destruiu"; em segundo lugar, que a vitória de tal princípio não é apenas um processo ideológico, mas "um real processo de transformação jurídica das relações humanas, que acompanha o desenvolvimento da economia mercantil e monetária" e "que engendra profundas e múltiplas modificações de natureza objetiva" (PACHUKANIS, 1988, p.10; 2003, p.38, passim). Em seguida, observa:

\footnotetext{
${ }^{20}$ Márcio Naves, por exemplo, observa: "A existência de um aparelho situado acima das partes em litígio do qual emanam, com força obrigatória, normas gerais e abstratas, depende do surgimento de um circuito de trocas que cria as condições básicas para que se opere a distinção entre o público e o privado, com todas as consequências daí derivadas. É, portanto, na esfera da circulação das mercadorias que podemos desvendar o segredo do Estado e das formas políticas burguesas". (NAVES, 2000, p.79). Mascaro segue a mesma linha: "A forma política estatal surgirá quando o tecido social, necessariamente, institua e seja instituído, reproduza e seja reproduzido, compreenda-se e seja compreendido, a partir dos termos da forma-mercadoria e também da forma jurídica - sujeito de direito -, vinculando-se então, inexoravelmente, ao plexo de relações sociais que se incumba de sua objetivação em termos políticos". (MASCARO, 2013, pp.25/26).

${ }^{21}$ Nesse sentido, Poulantzas anota: "A linha geral dessas análises é suficientemente conhecida: trocas de mercadorias entre proprietários 'privados' - esta propriedade privada considerada apenas a nível jurídico -, contrato de compra e venda da força-trabalho, troca equivalente e valor de troca abstrato etc. Este seria o terreno de emergência da igualdade e da liberdade 'formais' e 'abstratas', partículas isoladas da sociedade de troca - o indivíduo genérico - instauradas como 'indivíduos-pessoas' jurídico-políticos, da lei e da regra jurídica formal e abstrata como sistema de coesão dos comerciantes que trocam. A separação relativa do Estado e da economia é tomada como separação do Estado e da famosa "sociedade civil"'. (POULANTZAS, 2000, p.48).
} vol.09, nº 03, Rio de Janeiro, 2016. pp. 
Este conjunto de fenômenos compreende o surgimento e a consolidação da propriedade privada, a sua extensão universal tanto aos sujeitos como a todos os objetos possíveis; a libertação da terra das relações de domínio e de servidão; a conversão de toda a propriedade em propriedade mobiliária; o desenvolvimento e a preponderância das relações obrigacionais e, finalmente, a constituição de um poder político autônomo como particular forma de poder - ao lado do qual tem lugar o poder puramente econômico do dinheiro - assim como a subsequente divisão, mais ou menos profunda, entre a esfera das relações públicas e a das relações privadas, entre o direito público e o direito privado (PACHUKANIS, 1988, p.10; 2003, p.38, grifo meu).

Justamente essa chave interpretativa é posta em dúvida pela crítica mais recente ao pensamento de Pachukanis. Assinala-se que a centralidade da forma sujeito de direito e a consequente conformação da forma estatal a partir desta figura eclipsam o papel desempenhado pela luta de classes na estruturação da materialidade do Estado. Quer dizer, na visão do autor russo o poder estatal teria como centro gravitacional o relacionamento entre pessoas, proprietários privados de mercadorias, e não entre classes sociais, isto é, capitalistas e trabalhadores. Esse ponto de vista não apenas estaria em desacordo com o marxismo clássico, como representaria, na verdade, uma posição pré-marxista. Dentre os críticos de Pachukanis, Nicos Poulantzas ${ }^{22}$ desponta como dos mais ácidos:

Procurei demonstrar que esta concepção é insuficiente e particularmente falsa, porque ela procura o fundamento do Estado nas relações de circulação e nas trocas mercantis (o que é de qualquer forma uma posição pré-marxista) e não nas relações de produção, que têm um lugar determinante no conjunto do ciclo de reprodução ampliada do capital. Esta concepção empobrece consideravelmente as pesquisas sobre o Estado. E o que é mais, ao levantar a questão da especificidade institucional do Estado capitalista, torna impossível a articulação entre esse Estado-sociedade civil e o Estado-luta de classes: as classes sociais têm elas mesmas seu fundamento nas relações de produção. Não que esta concepção não encerre certos mecanismos institucionais importantes do Estado, pois o espaço de circulação do capital tem ele próprio efeitos sobre o Estado, mas ela omite o essencial (POULANTZAS, 2000, p.49) $)^{23}$.

Até que ponto a crítica de Poulantzas estaria correta? Em princípio, não há como negar que o encadeamento geral dos argumentos alinhavados por Pachukanis conduzem à conclusão de que, sob sua óptica, a forma do sujeito de direito é o elemento fundamental à conformação da estrutura do Estado, de maneira que a luta de classes estaria relegada, sim, a um segundo plano. Não obstante, a todo o momento, em Teoria geral do direito e marxismo, verifica-se o esforço do autor no sentido de integrar à análise o papel desempenhado pela luta de classes como elemento que também funda a forma estatal. Assim, em uma passagem, ele observa: “O Estado moderno,

\footnotetext{
22 Sobre a vida e obra de Poulantzas, confira-se: (MOTTA, 2014, pp.406/417).

${ }^{23}$ Essa posição de Poulantzas encontra-se em sua última fase, apresentada em $O$ Estado, o poder, o socialismo, de 1978, que se contrapõe às perspectivas de Pachukanis. Para uma abordagem sobre a periodização de sua obra e o anterior alinhamento à concepção do autor russo, consulte-se: (BARISON, 2014, pp.418/432). Sobre a
} influência de Louis Althusser e as críticas a Pachukanis, verifique-se: (GUERRERO, 2014, pp.469/481). vol.09, nº. 03, Rio de Janeiro, 2016. pp. 
no sentido burguês da palavra, surge no momento em que a organização do poder de grupo ou de classe abrange relações mercantis suficientemente extensas" (PACHUKANIS, 1988, p.92; 2003, p.136). Em outro local, o autor explica:

O Estado, enquanto organização de domínio de classe e enquanto organização destinada a travar as guerras externas, não necessita de interpretação jurídica e muito menos a permite. É um setor onde reina a chamada razão de Estado, que nada mais é do que o princípio da oportunidade pura e simples. A autoridade como fiador da troca mercantil, em contrapartida, não só pode exprimir-se na linguagem do direito, mas revelar-se ela própria, também, como direito e somente como direito, ou seja, confundir-se totalmente com a norma abstrata objetiva (PACHUKANIS, 1988, p.93; 2003, p.137).

Não obstante o esforço do autor, percebe-se que a luta de classes é integrada como elemento externo à lógica mercantil-jurídica e não como momento engendrado pela dinâmica interna do movimento da mercadoria e do direito. Justamente por isso, Pachukanis assinala que o Estado moderno surge no momento em que a organização do poder de classe abrange relações mercantis suficientemente extensas. Depreende-se então que, em primeiro lugar, as trocas mercantis lograram êxito e se espalharam por uma determinada sociedade e, somente depois, como consequência, a organização do poder de classe transforma-se em Estado. Tanto do ponto de vista histórico, como do ponto de vista lógico-categorial, a exposição está comprometida. No primeiro caso, o movimento é simultâneo; no segundo, a categoria do Estado deve ser "desdobrada" das categorias mercantis ${ }^{24}$. Em nenhuma hipótese, contudo, a luta de classes poderia ser "acoplada externamente" à lógica mercantil.

Nesse sentido, é preciso ressaltar que fulcro da questão gira em torno de compreender, como ensina Marx, que o capitalismo apenas se afirma como tal, quer dizer, somente se constitui como modo de produção dominante, com circulação mercantil generalizada, no momento em que a força de trabalho torna-se, ela mesma, uma mercadoria ${ }^{25}$. Desse modo, para que a teoria de Pachukanis não caia diante das críticas formuladas por aqueles que não veem a luta de classes no interior de sua exposição, é necessário averiguar se o autor russo lida com essa questão da maneira adequada. Em uma passagem de Teoria geral do direito e marxismo, ele anota:

\footnotetext{
${ }^{24}$ Em Sobre a questão judaica, o "Jovem” Marx já havia apresentado esse movimento de modo pertinente: “A constituição do Estado político e a dissolução da sociedade burguesa nos indivíduos independentes - cuja relação é baseada no direito, assim como a relação do homem que vivia no estamento e na guilda era baseada no privilégio - se efetiva em um só e mesmo ato (...) A revolução política decompõe a vida burguesa em seus componentes sem revolucionar esses mesmos componentes nem submetê-los à crítica. Ela encara a sociedade burguesa, o mundo das necessidades, do trabalho, dos interesses privados, do direito privado, como o fundamento de sua subsistência, como um pressuposto sem qualquer fundamentação adicional, e, em consequência, como sua base natural". (MARX, 2010, p.53, passim).

25 “O que caracteriza a época capitalista é, portanto, que a força de trabalho assume para o próprio trabalhador a forma de uma mercadoria que lhe pertence, razão pela qual seu trabalho assume a forma do trabalho assalariado. Por outro lado, apenas a partir desse momento universaliza-se a forma-mercadoria dos produtos do trabalho". (MARX, 2013, p. 245, nota de rodapé no 41; 1962, p. 184, nota de rodapé n 41).
} 
A submissão do operário assalariado ao capitalista e a sua dependência diante dele existe também sob uma forma imediata: o trabalho morto acumulado domina aqui o trabalho vivo. Contudo, a submissão deste mesmo operário ao Estado capitalista não é igual à sua dependência frente ao capitalista individual, que se encontra simplesmente disfarçada sob uma forma ideológica desdobrada. Não é a mesma coisa, primeiro porque existe aqui um aparelho particular independente dos representantes da classe dominante, situado acima de cada capitalista individual e que se estabelece como uma força impessoal. Não é também a mesma coisa, porque tal força impessoal não concretiza cada uma das relações de exploração. Com efeito, o assalariado não é coagido, política e juridicamente, a trabalhar para um determinado empresário, mas apenas vende-lhe a sua força de trabalho formalmente com base em um contrato livre. À medida que a relação de exploração se realiza formalmente como relação entre dois proprietários de mercadorias 'independentes' e 'iguais' dos quais um, o proletário, vende a sua força de trabalho, e outro, o capitalista, a compra, o poder político de classe pode revestir-se da forma de um poder público (PACHUKANIS, 1988, p.96; 2003, pp.140/141. Grifo meu, exceto em "determinado").

Perceba-se que, neste momento da exposição, Pachukanis aproxima-se de uma solução adequada para o problema na medida em que aponta para o fundamento do modo de produção capitalista, que consiste na forma mercadoria da força de trabalho. Enquanto permanece tratando dos "proprietários de mercadorias" que se encontram no mercado para aliená-las reciprocamente, o autor situa-se, de fato, numa posição "pré-marxista", naquilo que se tem denominado de "sociedade dos simples produtores de mercadorias". No entanto, quando desloca a análise para a compra e venda da força de trabalho, aí sim torna seu ponto de vista rigoroso porque vislumbra a apresentação categorial levada a cabo por Marx em O capital ${ }^{26}$. O segredo da forma Estado não se encontra na forma mercadoria ou na forma sujeito, consideradas de modo abstrato ou referidas aos "possuidores que se encontram no mercado". Encontra-se, pelo contrário, no desvendamento da forma mercadoria da força de trabalho e, portanto, da forma sujeito de direito do trabalhador assalariado. A partir daí é que a análise deve "retroagir" à compreensão da "sociedade de produção simples de mercadorias".

O nó da questão reside justamente aí: Pachukanis muito raramente desce às profundezas da sociedade capitalista para identificar na relação capital/trabalho, isto é, no embate entre classes sociais, o fundamento oculto da forma estatal e as razões pelas quais o Estado aparece como força "neutra" situada acima das partes ${ }^{27}$. Por outro lado, o ponto de vista adverso, que

\footnotetext{
${ }^{26}$ Nesse sentido, Gert Schäfer: "Não há nenhuma forma de existência e de consciência ideológica da sociedade capitalista que tenha uma importância maior do que a do salário (pelo trabalho). A forma usual da relação essencial de classes e da dominação, que é mediada 'de modo econômico' e que funda ao mesmo tempo a totalidade social, constitui a base das ideias de liberdade, de direito e de igualdade, geradas continuamente na sociedade que produz mercadorias (portanto, não somente de modo fictício na assim chamada sociedade dos simples produtores de mercadorias) ". (SCHÄFER, 1990, p.111).

${ }^{27}$ Ao criticar a burguesia e suas teorias "jurídicas" sobre o Estado, o autor assinala: "Ela, com efeito, jamais perdeu de vista, em nome da pureza teórica, o outro aspecto da questão, a saber, que a sociedade de classes não é somente um mercado onde se encontram os proprietários de mercadorias independentes, mas igualmente, e 
aponta a insuficiência da análise que ressalta a centralidade da circulação mercantil e da forma jurídica mostra-se também inadequado à apreensão do fenômeno estatal porque despreza justamente o elemento específico da sociedade capitalista, que é a forma mercadoria da força de trabalho e, consequentemente, a forma sujeito de direito do trabalhador ${ }^{28}$. Em outras palavras, ambos os pontos de vista são insuficientes quando tomados isoladamente, de maneira antinômica. A solução, obviamente, consiste em apreendê-los nos termos da dialética marxiana, de modo que a antinomia se dissolva em oposição.

\section{SOLUÇÃO À LUZ DA DIALÉTICA MARXIANA}

De que maneira devem ser abordadas as insuficiências de Teoria geral do direito e marxismo especialmente no que concerne à relação entre direito e Estado? Ora, desde que se pretenda uma crítica marxista, parece que a solução mais adequada consiste em buscar as respostas no contexto do pensamento de Karl Marx, sobretudo no interior de sua dialética, exposta em $\mathrm{O}$ capital $^{29}$. Trata-se, pois, de seguir a apresentação marxiana das leis econômicas do capital, identificando os momentos em que são expostos o direito, as classes e o Estado, e considerando que tais momentos são elementos constitutivos de seus sentidos categoriais ${ }^{30}$.

Assim, um primeiro passo já foi dado. Viu-se que, de acordo com Marx, as mercadorias não podem ir por si mesmas ao mercado e se trocar umas pelas outras. É necessário considerar seus guardiões, seus possuidores. Para que relacionem suas coisas umas com as outras, como

ao mesmo tempo, o campo de batalha de uma encarniçada guerra de classes, na qual o aparelho do Estado constitui uma arma bastante poderosa". (PACHUKANIS, 1988, p.103; 2003, p.150). Mesmo aqui, note-se que a referência à luta de classes é abstrata, pois não se aponta a forma específica desse conflito no capitalismo.

${ }^{28}$ Thiago Barison conclui de modo semelhante, embora sua análise desenvolva-se sob perspectiva distinta: "Pachukanis é acusado de economicista por derivar o direito das relações de produção ou, o que não muda as coisas, de 'circulacionista', por derivar o direito da circulação mercantil. Não vê, Poulantzas, todavia, que embora o conteúdo da legislação e das instituições estatais possam variar conforme a dinâmica das classes, não escapam, todavia, aos limites estruturais do nível político do modo de produção capitalista, limites que ele próprio identifica quando analisa o Estado - a estrutura de igualdade que nivela, individualiza e isola os agentes e que corresponde ao despojamento dos produtores diretos face aos meios de produção e às relações de dependência pessoal". (BARISON, 2014, p.427).

${ }^{29}$ Embora Marx não tenha apresentado explicitamente a forma estatal em $O$ capital, é possível extrair de sua obra elementos fundamentais para a formulação de uma teoria marxista do Estado. Joachim Hirsch, a propósito, anota: "Em $O$ capital, Marx se limitou à investigação da forma valor e das consequências decorrentes dela sobre o processo de reprodução econômica e o desenvolvimento das relações de classe. Ele não chegou à formulação de uma teoria do Estado. Entretanto, é possível realizar esse passo teórico apoiandose em sua obra e, consequentemente, desenvolver a forma política enquanto expressão do modo de socialização contraditório do capitalismo. Aí, encontra-se o elemento básico fundamental de uma teoria materialista do Estado". (HIRSCH, 2010, p.28). Registre-se, ademais, que esse percurso segue as indicações do próprio Pachukanis: "O futuro mostrará até que ponto minha concepção é frutuosa. Naturalmente, nesta breve tentativa, não poderia delinear os grandes traços de evolução histórica e dialética da forma jurídica. Para esse empreendimento servi-me, essencialmente, das ideias que encontrei em Marx". (PACHUKANIS, 1988, p.14; 2003, p.43).

${ }^{30}$ Nesse sentido, confira-se: (REICHELT, 2013, pp. 133/268) e (FAUSTO, 1987a, pp. 141/223). vol.09, $\mathrm{n}^{\circ}$. 03, Rio de Janeiro, 2016. pp. 
mercadorias, eles devem se comportar reciprocamente como pessoas. "Essa relação jurídica, cuja forma é o contrato, seja ela legalmente desenvolvida ou não, é uma relação volitiva, na qual se reflete a relação econômica" (MARX, 2013, pp. 159/160; 1962, pp. 99/100). O conteúdo da relação jurídica é dado pela própria relação econômica ${ }^{31}$.

É fundamental compreender que, a esta altura da exposição (capítulo 02, do Livro I, de O capital), Marx descreve o "mundo das mercadorias", quer dizer, um momento da sociedade capitalista em que as relações sociais são presididas estritamente pela lógica mercantil, de modo que equivalentes são trocados com fundamento nas relações de valor. Justamente por isso, os possuidores de mercadorias equalizam-se no mercado e assumem a forma de pessoas, isto é, sujeitos que gozam dos atributos de liberdade, igualdade, autonomia da vontade e propriedade como dados naturais.

Nesse passo da exposição, Marx não apenas não apresentou o capital, como sequer ingressou na circulação simples de mercadorias. Quer dizer, está muito distante de expor o conflito entre classes sociais. Em outras palavras, apresenta a maneira como o modo de produção capitalista aparece na superfície da sociedade, isto é, como é captado pelos agentes envolvidos em suas teias sociais quotidianas. Nos Grundrisse, ao tratar do método a ser utilizado na apresentação de sua crítica da economia política, Marx observa:

Nessa primeira seção, em que são considerados valor de troca, dinheiro, preço, as mercadorias sempre aparecem como dadas. A determinação formal é simples. Sabemos que elas exprimem determinações da produção social, mas a própria produção social é pressuposta. Mas elas não são postas nessa determinação. Dessa maneira, a primeira troca aparece, na verdade, como troca exclusivamente do supérfluo, que não submete nem determina a totalidade da produção. É o excedente existente de uma produção global, que se situa fora do mundo dos valores de troca. Da mesma forma, também na sociedade desenvolvida as coisas se apresentam na superfície como mundo de mercadorias imediatamente existente. Mas essa própria superfície aponta para além de si mesma, para as relações econômicas que são postas como relações de produção. Por isso, a articulação interna da produção constitui a segunda seção; sua síntese no Estado, a terceira; a relação internacional, a quarta; o mercado mundial, a conclusão, em que a produção é posta como totalidade, assim como cada um de seus momentos; na qual, porém, todas as contradições simultaneamente entram no processo (MARX, 2011, pp.170/171).

Como explica Marx, "também na sociedade desenvolvida as coisas se apresentam na superfície como mundo das mercadorias imediatamente existente". Quer dizer, esse primeiro momento, em que os guardiões se encontram no mercado e assumem o caractere de pessoas, é o

\footnotetext{
${ }^{31}$ Não procede, portanto, o argumento de Sonja Buckel, segundo o qual, para Pachukanis, a forma jurídica teria sido "reduzida à função de viabilizar a troca de mercadorias" (BUCKEL, 2014, p.273). Atribuir sentido "funcional" à forma jurídica equivale a promover uma secção entre economia e direito, o que não existe em Pachukanis. Para este, ambos os elementos são faces da mesma moeda. Cerroni vai ao ponto: "Mas a sua investigação realiza, pelo menos, um progresso em relação a Stutchka, na medida em que reconstitui a relação vol.09, nº. 03, Rio de Janeiro, 2016. pp. 
momento em que os sujeitos de direito aparecem na pureza de sua forma e que corresponde ao modo como o senso comum capta a realidade efetiva. São proprietários privados de mercadorias, dotados de liberdade e igualdade. Suas vontades autônomas ajustam-se de modo que o contrato, a forma da relação jurídica, expressa os contornos singulares do intercâmbio concreto. Se a apresentação do direito interrompe-se aí, nesse momento superficial, então, de fato, recai-se numa posição "pré-marxista", pois esses elementos são justamente aqueles tomados pelos ideólogos burgueses para a formulação de suas teorias jurídicas e políticas, tais como a do contrato social, por exemplo. Obviamente, Marx não faz isso, já que este é apenas o primeiro momento de sua exposição ${ }^{32}$. Tampouco Pachukanis se prende a $\hat{i}^{33}$, muito embora o método de sua apresentação seja problemático nesse ponto, como se verá logo mais.

O próximo passo para a construção de significados mais concretos para as categorias que exprimem a troca mercantil, a relação jurídica, a forma sujeito de direito etc., é compreender que o encontro dos guardiões de mercadorias desdobra-se, necessariamente, em circulação mercantil, isto é, múltiplos atos de troca que se encadeiam no tempo e no espaço, formando um circuito pelo qual valores de uso transferem-se de mãos em mãos com o objetivo de suprir necessidades sociais. Marx chama esse movimento de circulação simples de mercadorias, que assume a forma M-D-M, ou seja, mercadoria (M) que é trocada por dinheiro (D) que, por sua vez, é trocado novamente por mercadoria $(\mathrm{M})$. A "novidade" com relação à troca direta $(\mathrm{M}-\mathrm{M})$ é que o dinheiro ocupa o meio-termo da equação, o que dá ensejo à autonomização do valor com relação ao valor de troca. Não obstante, ambos os extremos são formados por mercadorias, de maneira que a finalidade do movimento ainda é o valor de uso.

economia-direito, não só como uma relação historicamente determinada, mas ainda como um nexo unitário que estrutura uma mesma e global relação social”. (CERRONI, 1976, p.69).

${ }^{32}$ Helmut Reichelt explica: “Anteriormente já demos a entender que Marx desenvolve as categorias na mesma sequência em que ocorrem na sociedade burguesa, por assim dizer, como uma espécie de corte transversal da estrutura do capitalismo desdobrado. Ele pressupõe que a produção total assume a forma-mercadoria, o que ocorre somente no caso do capitalismo desenvolvido. Pois, de acordo com a concepção de Marx, só agora é que a lei do valor passa a vigorar plenamente, possibilitando, desse modo, também um olhar para dentro da estrutura do capital e de todas as formações sociais precedentes. Por esse pressuposto, contudo, a troca de mercadorias de modo algum constitui um processo de troca simples, mas um momento da circulação do capital. Desse ponto de vista, a exposição dialética das categorias é a desconstrução impulsionada paulatinamente da concepção burguesa do encontro de indivíduos livres e iguais na esfera da circulação: no final da exposição, ficará evidente que é o próprio capital que vem ao nosso encontro em diferentes formas, todas elas identificando-se como momentos dele próprio”. (REICHELT, 2013, p.171, grifo meu).

${ }^{33}$ Pachukanis anota: "Isto foi expresso de maneira um tanto quanto ingênua pelos teóricos do direito natural que fundamentaram sua teoria do poder na ideia de relações entre pessoas independentes e iguais e que julgaram por isso partir dos princípios das relações humanas como tais. Na verdade, não fizerem mais do que explanar, sob diferentes matizes, a ideia de um poder que une entre si os proprietários de mercadorias independentes. Essa é a razão dos traços fundamentais desta doutrina que, de forma bastante nítida, aparecem já em Grotius" (PACHUKANIS, 1988, p.98; 2003, p.143). 
Do ponto de vista jurídico, importa notar que o circuito é todo mediado por relações contratuais, que agora assumem a forma de venda (M-D) e compra (D-M). Se no encontro dos guardiões de mercadorias o ato de troca e, portanto, a forma jurídica que o expressa, aparecem isoladamente, agora a apresentação dá conta de que por trás desse ato singular existe, na verdade, uma cadeia ampla de múltiplas relações de intercâmbio mercantil e, como consequência, de contratos de compra e venda. Aquela percepção inicial, ainda muito jungida à superfície da sociedade, desdobra-se agora na compreensão de que o "mundo da mercadoria" é, na verdade, "mundo da circulação". Como consequência, percebe-se que as relações jurídicas englobam de modo totalizante a sociedade do capital, perfazendo uma superestrutura jurídica concreta. Pachukanis observa:

A crescente divisão do trabalho, a melhoria das comunicações e o consecutivo desenvolvimento das trocas fazem do valor uma categoria econômica, ou seja, a encarnação das relações sociais de produção que dominam o indivíduo. Mas para isso é preciso que os diferentes atos acidentais da troca se transformem numa circulação alargada e sistemática de mercadorias. Neste estágio de desenvolvimento, o valor distingue-se das avaliações ocasionais, perde seu caráter de fenômeno psíquico individual e assume um significado econômico objetivo (...) A capacidade de ser sujeito jurídico desprende-se, então, definitivamente, da personalidade concreta, vivente, deixa de ser uma função de sua vontade consciente, eficaz e transforma-se em pura propriedade social. A capacidade de agir é abstraída da capacidade jurídica, o sujeito jurídico recebe um duplo na pessoa de um representante e adquire ele mesmo a significação de um ponto matemático, de um núcleo onde se concentra certa soma de direitos (PACHUKANIS, 1988, p.73; 2003, pp.114/115).

É fundamental compreender, no entanto, que a circulação simples de mercadorias (M-D -M), embora esteja impregnada de juridicidade, signifique verdadeiro "éden dos direitos do homem" e apresente-se como substrato natural da forma sujeito de direito, ainda assim, não representa senão a face externa do modo de produção capitalista, isto é, a maneira como o sistema aparece para aqueles que vivem suas relações sociais quotidianas ${ }^{34}$.

Isso significa que existe outro movimento, correndo pelas costas dos agentes mercantis, e que aponta para o fundamento do modo de produção capitalista, quer dizer, para a relação social que abrange e confere sentido a todas as outras. Esse movimento é apresentado pela primeira vez por Marx no capítulo 04 de O capital, ou seja, depois da exposição da troca de mercadorias e da circulação simples. Diz o autor:

A circulação de mercadorias é o ponto de partida do capital. Produção de mercadorias e circulação desenvolvida de mercadorias - o comércio - formam os pressupostos históricos a partir dos quais o capital emerge. O comércio e o

\footnotetext{
${ }^{34}$ Ruy Fausto observa: "Deve-se retomar agora a tese de que partimos, tese que diz que o objeto da secção primeira é a circulação simples, e que a circulação simples é a aparência do modo de produção capitalista. A circulação simples é a aparência do modo de produção capitalista: isto significa que, considerado num nível puramente fenomenal, o sistema nos revela um conjunto de intercâmbios que tomados em si mesmos se apresentam como simples intercâmbios de mercadorias". (FAUSTO, 1987a, p.183).
} vol.09, $\mathrm{n}^{\mathrm{o}}$. 03, Rio de Janeiro, 2016. pp. 
mercado mundiais inauguram, no século XVI, a história moderna do capital (...) A forma imediata da circulação de mercadorias é M-D-M, conversão de mercadoria em dinheiro e de dinheiro em mercadoria, vender para comprar. Mas ao lado dessa forma encontramos uma segunda, especificamente diferente: a forma D-M-D, conversão de dinheiro em mercadoria e reconvenção de mercadoria em dinheiro, comprar para vender. $\mathrm{O}$ dinheiro que circula deste último modo transforma-se, torna-se capital e, segundo sua determinação, já é capital (MARX, 2013, pp. 223/224; 1962, p. 162, passim).

Ora, se o objeto de investigação de Marx é o sistema econômico capitalista, suas relações de produção e circulação ${ }^{35}$, é claro que a análise marxiana apenas começa a encaminhar-se para o desvendamento das relações sociais ocultas que constituem o fundamento da sociedade no momento em que a forma do capital é apresentada. Até então, como ressaltado, apresentou-se o modo de aparecimento do sistema, que consiste em relações de trocas simples de mercadorias ${ }^{36}$. Nesse sentido, a circulação complexa, ou como afirma Marx, a circulação do dinheiro como capital (D-M-D), resume a fórmula geral do capital, forma na qual ele determina a organização econômica da sociedade moderna ${ }^{37}$. O "mundo das mercadorias", que havia se desdobrado em "mundo da circulação", agora aponta para aquilo que constitui seu fundamento: “mundo do capital”, isto é, a forma social cuja finalidade é a produção e ampliação de valor.

Assim, qualquer análise marxista do direito, na medida em que pretenda avançar de modo significativo, ou seja, que busque ultrapassar as formas fenomenais, aparentes, que caracterizam a sociedade capitalista em sua face exterior, deve, necessariamente, integrar a análise do direito à luz da circulação complexa (D-M-D’), considerando sempre que, por representar a forma geral do capital, expressa o modo pelo qual se determina a organização econômica da sociedade moderna. Em outras palavras, a análise do direito à luz das trocas diretas e da circulação simples é absolutamente insuficiente para a crítica marxista do direito, que, desse modo, corre o risco de recair num ponto de vista "pré-marxista".

Não obstante, esse é justamente o ponto fraco de Pachukanis. A exposição que desenvolve em Teoria geral do direito e marxismo permanece predominantemente atada a categorias que exprimem a circulação simples (M-D-M). Observe-se: não se trata de afirmar que autor não esteja tratando da economia capitalista ou que não exponha categorias que remetam ao capital. Nada disso! Ao longo de sua obra, percebe-se claramente que Pachukanis

\footnotetext{
35 “O que pretendo nesta obra investigar é o modo de produção capitalista e suas correspondentes relações de produção e de circulação”. (MARX, 2013, p.78; 1962, p.12).

${ }^{36}$ Helmut Reichelt explica: "Por essa razão, constitui uma abstração inaugurar a exposição das categorias com a explicação da circulação simples das mercadorias, porque de qualquer modo já é o próprio capital que se apresenta dessa forma; no entanto, outra forma de exposição não é possível, porque o capital pressupõe o valor em termos lógicos e históricos”. (REICHELT, 2013, p.258).

${ }^{37}$ Diz Marx: "Compreende-se, assim, por que, em nossa análise da forma básica do capital, forma na qual ele determina a organização econômica da sociedade moderna, deixamos inteiramente de considerar suas formas vol.09, nº. 03, Rio de Janeiro, 2016. pp. 
compreende o direito no interior do modo de produção capitalista e desenvolve suas determinações conceituais à luz desse contexto social. O que se quer acentuar, contudo, é que sua apresentação categorial se cinge, com predominância, às formas da circulação simples, o que acaba por comprometer sua análise em certas questões. Pachukanis dá evidências muito claras de que se move através dessas categoriais. No prefácio à $2^{\mathrm{a}}$ edição, ele observa:

As coisas apresentam-se, por exemplo, da seguinte maneira no que concerne à propriedade privada: só o momento da livre alienação revela plenamente a essência fundamental desta instituição, ainda que, sem sombra de dúvida, a propriedade, como apropriação, tenha existido antes como forma não só desenvolvida como também muito embrionária, da troca. A propriedade como apropriação é a consequência natural de qualquer modo de produção; porém, a propriedade só reveste a sua forma lógica mais simples e mais geral de propriedade privada quando se tem em vista o núcleo de uma determinada formação social onde ela é determinada como a condição elementar da ininterrupta circulação dos valores que se opera de acordo com a fórmula Mercadoria-Dinheiro-Mercadoria (PACHUKANIS, 1988, pp.13/14; 2003, pp.42/43).

Veja-se que Pachukanis elabora categorialmente o conceito de propriedade privada que, segundo ele, apenas é possível na sociedade burguesa. O momento da livre alienação revela a essência fundamental desta instituição e isso somente é possível quando se tem em vista o "núcleo de uma determinada formação social onde ela é determinada como condição elementar da ininterrupta circulação dos valores que se opera de acordo com a fórmula MercadoriaDinheiro-Mercadoria". Ora, como visto, de acordo com Marx, "a forma que determina a organização econômica da sociedade moderna" é a forma geral do capital, expressa pela circulação complexa (D-M-D'). Note-se que, embora Pachukanis esteja, sim, tratando do modo de produção capitalista, mantém sua apresentação jungida a categorias que expressam a circulação simples de mercadorias.

É curioso notar que o autor não estava alheio a esse problema, apontado por Stutchka algum tempo depois da publicação de Teoria geral do direito e marxismo. Em um texto de 1927, denominado A teoria marxista do direito e a construção do socialismo, o autor observa:

A relação de dois possuidores de mercadorias, como base real de toda a riqueza das construções jurídicas, é ela própria uma abstração bastante vazia. Atrás da vontade do possuidor de mercadorias muita coisa se esconde: a vontade do capitalista, a vontade do pequeno produtor de mercadorias, a vontade do operário que vende a sua única mercadoria - a força de trabalho. A clareza formal da transação jurídica nada diz sobre seu conteúdo de classe econômico e social. O camarada Stutchka assinala esse lado do problema, conclamando-nos fundamentalmente a 'só permanecer na abstrata sociedade de simples produtores de mercadorias o tempo necessário para revelar os mistérios das abstrações do direito burguês. Feito isso, retornemos à realidade, à sociedade de classes'. É pouco provável que se possa objetar algo contra tal

populares e, por assim dizer, antediluvianas: o capital comercial e o capital usurário". (MARX, 2013, p.239; 1962, p.178, grifo meu). vol.09, nº. 03, Rio de Janeiro, 2016. pp. 
apelo. A interpretação do significado das categorias jurídicas formais não as priva desse caráter formal, e não afasta o perigo de uma certa reincidência da ideologia jurídica, maquiada por um protetor tom marxista. Particularmente, é indiscutível a assertiva de P. I. Stutchka de que a vontade do possuidor de mercadorias numa simples sociedade de produtores de mercadorias, e a vontade do possuidor de mercadorias capitalista são qualitativamente vontades distintas, apesar de elas manterem uma idêntica aparência formal nas transações de compra e venda. O sentido da vontade se expressa, em um caso, na fórmula $\mathrm{M}-\mathrm{D}-\mathrm{M}$, e no outro, na fórmula $\mathrm{D}-\mathrm{M}-\mathrm{D}+\mathrm{d}$. Toda a importância dessa distinção se revelou claramente a nós devido à última discussão no interior do Partido, quando fomos obrigados a lutar contra a aplicação não crítica do termo 'economia privada', e a demonstrar a necessidade de uma rigorosa distinção entre a produção capitalista privada, por um lado, e a produção simples de mercadorias, isto é, a economia camponesa, por outro (PACHUKANIS, 2009, pp.146/147).

Pois bem, de que modo esse limite categorial repercute na concepção de Pachukanis sobre o Estado e por que razão isso fragiliza sua teoria? Ora, uma vez que o autor fica preso nas determinações da troca e circulação simples de mercadorias, encontra-se como que "bloqueado" seu acesso às classes sociais. De fato, esses momentos, que aparecem de modo superficial na sociedade capitalista, revelam apenas sujeitos de direitos, quer dizer, pessoas trocando com liberdade no mercado. A circulação de mercadorias é marcada pelo princípio da equivalência, de maneira que não há extração de sobretrabalho e, portanto, a presença de classes sociais. Bloqueado o acesso a esta dimensão da sociedade capitalista, contudo, a forma estatal é apresentada sempre de modo parcial, pois o acento recai a todo o momento na concepção do Estado como poder que se eleva sobre sujeitos que operam no mercado com base no princípio da igualdade. Não obstante, nos termos de uma dialética marxiana, o acesso à forma estatal deve necessariamente passar pela apresentação prévia das classes sociais. Essa exigência não advém apenas das obras de juventude de Marx. Encontra-se, pelo contrário, na sua crítica da economia política, especificamente no Livro III de O capital:

A forma econômica específica em que se suga mais-trabalho não pago dos produtores diretos determina a relação de dominação e servidão, tal como esta surge diretamente da própria produção e, por sua vez, retroage de forma determinante sobre ela. Mas nisso é que se baseia toda a estrutura da entidade comunitária autônoma, oriunda das próprias relações de produção e, com isso, ao mesmo tempo sua estrutura política peculiar. É sempre na relação direta dos proprietários das condições de produção com os produtores diretos - relação da qual cada forma sempre corresponde naturalmente a determinada fase do desenvolvimento dos métodos de trabalho, e, portanto, a sua força produtiva social - que encontramos o segredo mais íntimo, o fundamento oculto de toda a construção social $\mathrm{e}$, por conseguinte, da forma política das relações de soberania e de dependência, em suma, de cada forma específica de Estado. Isso não impede que a mesma base econômica - a mesma quanto às condições principais - possa, devido a inúmeras circunstâncias empíricas distintas, condições naturais, relações raciais, influências históricas externas etc., exibir variações e graduações em sua manifestação, que só podem ser entendidas mediante análise dessas circunstâncias empiricamente dadas. (MARX, 1988, pp. 235/236; 1971, pp. 799/800). 
Perceba-se que, de acordo com Marx, "é sempre na relação direta dos proprietários das condições de produção com os produtores diretos" - o que, no capitalismo, significa a relação entre capitalistas e trabalhadores -, que se encontra o "segredo mais íntimo, o fundamento oculto de toda a construção social", portanto, "de cada forma específica de Estado". Assim, não há como apresentar a forma do Estado partindo imediatamente das formas mercantil e do sujeito de direito, sem passar, antes, pela exposição das relações entre classes sociais. Não há dúvida de que Pachukanis "pressente" a questão, pois a todo o momento tenta fazer ingressar na estrutura de sentido da categoria que expressa sua concepção de Estado a "luta de classes". No entanto, como não desenvolveu as mediações necessárias, ou seja, não acompanhou a apresentação categorial de Marx em O capital de modo satisfatório, acaba enredando-se em construções "artificiais", tais como esta:

Os proprietários de mercadorias livres e iguais, que se encontram no mercado, só o são na relação abstrata da apropriação e da alienação. Na realidade eles estão mutuamente unidos por todas as espécies de vínculos de dependência recíproca. Deste modo, por exemplo, o pequeno comerciante e o atacadista, o camponês e o latifundiário, o devedor arruinado e seu credor, o proletário e o capitalista. Todas estas infinitas relações de concretas dependências fixam o fundamento real da organização estatal (PACHUKANIS, 1988, p.101; 2003, pp. 146/147).

Do ponto de vista de uma apresentação categorial do modo de produção capitalista tal como desenvolve Marx em $\mathrm{O}$ capital, não faz muito sentido equiparar as relações entre camponês e latifundiário às relações entre proletário e capitalista. Uma vez que o capitalismo esteja definitivamente estabelecido, aquela relação ou não existe ou existe apenas marginalmente. Por outro lado, o fundamento da economia capitalista e, portanto, a forma capaz de revelar o segredo oculto de toda a estrutura social e, como consequência, a forma específica do Estado capitalista, é a relação entre capitalistas e trabalhadores assalariados. No entanto, como Pachukanis sabe que uma análise do Estado não pode desprezar os vínculos entre classes sociais, a todo o momento faz ingressar tais relações em sua exposição. Ao fazê-lo, contudo, acaba por "violentar" o modo dialético de exposição, pois não desdobra as categorias posteriores a partir das anteriores, mas as introduz externamente, o que engendra complicações em sua análise da forma estatal.

Em suma, a concepção de Pachukanis sobre o Estado está marcada por um certo vácuo categorial porque o autor desdobra a forma do Estado diretamente da troca e circulação mercantil simples, sem passar, antes, pela apresentação explícita do capital e das relações entre classes sociais. Estas, no entanto, constituem o fundamento oculto do edifício social, as relações infraestruturais que conformam os alicerces da totalidade e conferem sentido aos aspectos particulares do organismo social, inclusive e especialmente ao Estado. Desse modo, sua teoria 
acaba exposta a críticas que assinalam a ausência da luta de classes em sua análise ${ }^{38}$. A solução passa por integrar a concepção de Pachukanis à análise que Marx faz em $\mathrm{O}$ capital porque a dialética marxiana elimina satisfatoriamente as lacunas de Teoria geral do direito e marxismo e permite responder adequadamente aos críticos do autor russo.

\section{CONCLUSÃO}

Do quanto foi exposto deve-se concluir, então, que a obra de Pachukanis está marcada por um problema teórico irremediável, que compromete todo o rigor da análise? Obviamente, não! Teoria geral do direito e marxismo significou uma pequena revolução teórica quando foi publicado $^{39}$. Mesmo com o tempo transcorrido, o pensamento do autor russo ainda mantém todo o vigor de sua originalidade e, sem dúvida, é o marco essencial da crítica marxista do direito. Ao delimitar o objeto de estudo a partir de O capital, Pachukanis estabelece os contornos fundamentais de todo o debate subsequente a ser desenvolvido no interior do marxismo. Além do mais, diga-se de passagem, na época em que publicou seu ensaio grande parte dos problemas aqui levantados estava simplesmente fora dos horizontes teóricos do marxismo. Apenas para exemplificar, História de consciência de classe, que inaugura o conjunto de preocupações mais substanciais a respeito da dialética no interior do marxismo, foi publicado em 1923, ou seja, apenas um ano antes de Teoria geral do direito e marxismo. Sob esta perspectiva, a originalidade de Pachukanis é ainda mais evidente.

Os apontamentos deste artigo visam menos a obra de Pachukanis, e mais a crítica marxista do direito que se tem produzido nos últimos tempos. De fato, basta passar em revista a bibliografia sobre o assunto para perceber que se tem, como regra, um conjunto de descrições acríticas sobre as principais categorias utilizadas em Teoria geral do direito e marxismo, tais como forma mercantil e jurídica, sujeito de direito, extinção da forma jurídica sob o socialismo etc., sem maiores preocupações quanto à correspondência com a realidade atual. Em outras palavras, o capitalismo deste início de Século XXI é distinto daquele com o qual Pachukanis conviveu, no começo do Século XX. Os problemas são completamente outros, e as soluções demandam posturas teóricas diferentes. Não obstante, a crítica marxista parece acomodada,

\footnotetext{
${ }^{38}$ A propósito da pergunta clássica de Pachukanis, sobre por que a dominação de classe não aparece como é, mas na forma de um aparato estatal, Ruy Fausto anota: "Uma parte da resposta já se encontra em Pasukanis, mas ela não está desenvolvida de um modo inteiramente satisfatório. É a partir do conjunto da apresentação do livro I de $O$ capital que se poderia obter uma resposta rigorosa" (FAUSTO, 1987b, p.291).

${ }^{39}$ Márcio Naves observa: "A teoria geral do direito e o marxismo teve o efeito de uma pequena revolução teórica na jurisprudência. Pachukanis, rigorosamente, retorna a Marx, isto é, não apenas às referências ao direito encontradas em $O$ capital - e não seria exagero dizer que ele é o primeiro que verdadeiramente as lê - 
escusando-se de estudos que conduzam a indagações mais aprofundadas. Ao fim e ao cabo, não podemos nos furtar a dar prosseguimento ao trabalho de Pachukanis. Afinal de contas, não era outro seu desejo:

Minha tarefa não era a de resolver em definitivo todos os problemas da teoria do direito ou mesmo apenas alguns. Meu desejo era mostrar unicamente sob que ângulo é possível abordá-los e como de devem equacionar os problemas. Fico contente em saber que alguns marxistas tenham considerado que a minha posição sobre as questões do direito é interessante e oferece perspectivas. E isto é o que ainda me mantém no desejo de prosseguir o trabalho pela via iniciada (PACHUKANIS, 1988, p.14; 2003, pp.43/44).

\title{
NOTES ON LAW AND STATE IN GENERAL THEORY OF LAW AND MARXISM
}

\begin{abstract}
The article has as subject the work of Evgeny Pashukanis, General Theory of Law and Marxism, published in 1924, in the Soviet Union. It starts with the author's original conception, which does approaching the commodity form to juridical form, to identify the specific nature of relationship between law and state in its analysis. Bounded on the issue, tries to emphasize the theoretical limits of his theory, especially the permanence in categories that express the simple circulation of commodities, which relegates to background the complex circulation and the buying and selling of labor power. As result, the class struggle ends up occupying a lower analytical plan, which commits, in part, his conception on the state. It concludes pointing interpretive paths that supply the lack of important categorical connections, always in light of Marxian dialectic.
\end{abstract}

Keywords: Marxism and law; commodity form and juridical form; Law and state; Evgeny Pashukanis; Marxist critique of law and the state.

\section{REFERÊNCIAS BIBLIOGRÁFICAS}

ALVES, Alaôr Caffé. Estado e Ideologia: aparência e realidade. São Paulo: Editora Brasiliense, 1987.

"Apresentação da edição brasileira". In: PACHUKANIS, Evgeny. Teoria geral do direito e marxismo. Tradução de Sílvio Donizete Chagas. São Paulo: Editora Acadêmica, 1988.

BARISON, Thiago. "Nicos Poulantzas e o direito: entre Pachukanis e Stuchka". In: Revista Questio Iuris, vol. 07, $\mathrm{n}^{\circ}$ 02, Rio de Janeiro, 2014, pp. 418-432. Disponível em: <http://www.epublicacoes.uerj.br/index.php/quaestioiuris/article/view/13418/10319> Acesso: 03/12/2015.

BUCKEL, Sonya. “'A forma na qual as contradições podem se mover': para a reconstrução de uma teoria materialista do Direito". In: Revista Direito e Práxis, vol. 05, nº 09, Rio de Janeiro,

mas, principalmente, ele retorna à inspiração original de Marx, ao recuperar o método marxiano" (NAVES, 2000, p.16). vol.09, n. 03, Rio de Janeiro, 2016. pp. 
2014, pp. 366-385. Disponível em: <http://www.epublicacoes.uerj.br/index.php/revistaceaju/article/view/13652/10652> Acesso em 03/12/2015.

CASALINO, Vinícius. O direito e a mercadoria: para uma crítica marxista da teoria de Pachukanis. São Paulo: Dobra Editorial, 2011.

CERRONI, Umberto. O pensamento jurídico soviético. Tradução de Maria de Lurdes Sá Nogueira. Póvoa de Varzim (Portugal): Publicações Europa-América, 1976.

EDELMAN, Bernard. O direito captado pela fotografia: elementos para uma teoria marxista do direito. Trad. Soveral Martins e Pires de Carvalho. Coimbra: Centelha, 1976.

ENGELS, Friedrich. A origem da família, da propriedade privada e do Estado: trabalho relacionado com as investigações de L. H. Morgan. $16^{\mathrm{a}}$ ed. Tradução de Leandro Konder. Rio de Janeiro: Bertrand Brasil, 2002.

FAUSTO, Ruy. Marx: Lógica e Política: investigações para uma reconstituição do sentido da dialética. Tomo I. $2^{a}$ ed. São Paulo: Editora Brasiliense, 1987a.

Marx: Lógica e Política: investigações para uma reconstituição do sentido da dialética. Tomo II. São Paulo: Editora Brasiliense, 1987b.

GUERRERO, Cristóbal Ramos. "Marxismo y derecho: sobre la crítica de Poulantzas a Pashukanis y Stuchka". In: Revista Quaestio Iuris, vol. 07, n02, Rio de Janeiro, 2014, pp. 469481. Disponível em: <http://www.epublicacoes.uerj.br/index.php/quaestioiuris/article/view/13421/10289 > Acesso: 03/12/2015.

HIRSCH, Joachim. Teoria materialista do Estado: processos de transformação do sistema capitalista de Estados. Tradução de Luciano Cavini Martorano. Rio de Janeiro: Revan, 2010.

HEGEL, Georg W. F. Princípios da filosofia do direito. Tradução de Orlando Vitorino. São Paulo: Martins Fontes, 1997.

KASHIURA JR, Celso Naoto. Crítica da igualdade jurídica: contribuição ao pensamento jurídico marxista. São Paulo: Quartier Latin, 2009.

LENIN. Vladimir I. O estado e a revolução: o que ensina o marxismo sobre o Estado e o papel do proletariado na revolução. Tradução de Aristide Lobo. São Paulo: Editora Hucitec, 1986.

LUCKÁCS, Georg. História e consciência de classe: estudos sobre a dialética marxista. Tradução: Rodnei Nascimento. São Paulo: Martins Fontes, 2003.

MARX, Karl. O capital: crítica da economia política. Livro I: o processo de produção do capital. Tradução de Rubens Enderle. São Paulo: Boitempo, 2013.

O capital: crítica da economia política. Livro III: o processo global da produção capitalista. $3^{a}$ ed. Tradução de Regis Barbosa e Flávio R. Kothe. Vol. V. T. 02. São Paulo: Nova Cultural, 1988 (Os economistas).

Das Kapital: Kritik der politischen Ökonomie. Erster Band. Buch I: der produktionsprozeß des Kapitals. Berlin: Dietz Verlag, 1962.

Das Kapital: Kritik der politischen Ökonomie. Dritter Band. Buch III: Der Gesamtprozess der kapitalistischen Produktion. Berlin: Dietz Verlag, 1971. 
Grundrisse: manuscritos econômicos de 1857-1858: esboços da crítica da economia política. Tradução de Mario Duayer e Nélio Schneider, com a colaboração de Alice Helga Werner e Rudiger Hoffman. São Paulo: Boitempo; Rio de Janeiro: Editora UFRJ, 2011.

Contribuição à crítica da economia política. $3^{\mathrm{a}}$ ed. Tradução de Maria Helena Barreiro Alves. São Paulo: Martins Fontes, 2003.

Sobre a questão judaica. Tradução de Nélio Schneider. São Paulo: Boitempo, 2010.

ENGELS, Friedrich. Manifesto comunista. Tradução de Álvaro Pina. São Paulo: Boitempo editorial, 1998.

Das kommunistische Manifest. Köln (Alemanha): Anaconda Verlag, 2009.

MASCARO, Alysson Leandro. Crítica da legalidade e do direito brasileiro. São Paulo: Quartier Latin, 2003.

Estado e forma política. São Paulo: Boitempo, 2013.

MASTRODI, Josué; FURQUIM, Gabriel Martins. "Pachukanis e o abolicionismo penal de Hulsman e Christie". In: Revista Direito e Práxis, vol. 5, nº 9, Rio de Janeiro, 2014, pp. 150$175 . \quad$ Disponível em: <http://www.epublicacoes.uerj.br/index.php/revistaceaju/article/view/10507/10644> Acesso: 03/12/2015.

MOTTA, Luiz Eduardo. "Nicos Poulantzas: para além do conceito de Estado moderno". In: Revista Quaestio Iuris, vol. 07, $\mathrm{n}^{\circ}$ 02, Rio de Janeiro, 2014, pp.406-417. Disponível em: <http://www.e-publicacoes.uerj.br/index.php/quaestioiuris/article/view/13417/10316> Acesso: $03 / 12 / 2015$.

NAVES, Márcio Bilharinho. Marxismo e direito: um estudo sobre Pachukanis. São Paulo: Boitempo Editorial, 2000.

(org.). O discreto charme do direito burguês: ensaios sobre Pachukanis. Campinas (SP): UNICAMP, Instituto de Filosofia e Ciências Humanas, 2009,

PACHUKANIS, Evgeny. Teoria geral do direito e marxismo. Tradução de Sílvio Donizete Chagas. São Paulo: Editora Acadêmica, 1988.

Allgemeine Rechtslehre und Marxismus. Tradução de Edith Hajós. Freiburg: ça ira Verlag, 2003.

A teoria marxista do direito e a construção do socialismo. Tradução de Lidia C. Ferreira e Márcio Bilharinho Naves. In: NAVES, Márcio Bilharinho. O discreto charme do direito burguês: ensaios sobre Pachukanis. Campinas (SP): UNICAMP, Instituto de Filosofia e Ciências Humanas, 2009.

POULANTZAS, Nicos. O Estado, o poder, o socialismo. $4^{\text {a }}$ ed. Traduzido por Rita Lima. Rio de Janeiro: Edições Graal; São Paulo: Editora Paz e Terra, 2000.

REICHELT, Helmut. Sobre a estrutura lógica do conceito de capital em Karl Marx. Tradução de Nélio Schneider. Campinas (SP): Editora da UNICAMP, 2013.

SARTORI, Vitor Bartoletti. "Teoria geral do direito e marxismo de Pachukanis como crítica marxista ao direito". In: Verinotio, $\mathrm{n}^{\mathrm{o}}$ 19, 2014, pp. 36-60. Disponível em: <http://verinotio.org/Verinotio_revistas/n19/4_art_sartori.pdf> Acesso em: 04/12/2015.

SCHÄFER, Gert. "Alguns problemas decorrentes da relação entre dominação 'econômica' e 'política"'. In: REICHELT, Helmut (et al). A teoria do estado: materiais para a reconstrução da teoria marxista do Estado. Tradução de Flávio Beno Siebeneichler. Rio de Janeiro: Tempo Brasileiro, 1990. 
STUTCHKA, Piotr. Direito de classe e revolução socialista. $2^{\text {a }}$ ed. Tradução: Emil Von München. São Paulo: Instituto José Luís e Rosa Sundermann, 2001.

Trabalho enviado em 07 de dezembro de 2016.

Aceito em 03 de março de 2016. 